\title{
Geochemistry, provenance, and tectonic significance of sedimentary rocks of the Middle to Late Devonian McArras Brook and Viséan Martin Road formations, Merigomish Subbasin, northern Antigonish Highlands, Nova Scotia
}

\author{
J. Brendan Murphy \\ Department of Earth Sciences, St. Francis Xavier University, Antigonish, NS B2G $2 W 5$ \\ <bmurphy@stfx.ca>
}

Date Received: January 11, 2002

Date Accepted: May 24, 2002

\begin{abstract}
The Merigomish Subbasin occurs along the southern flank of the composite Late Devonian-Permian Maritimes Basin of Atlantic Canada. The subbasin consists predominantly of Viséan to Westphalian clastic rocks that overlie Middle to Late Devonian basalt and continental clastic rocks of the McArras Brook Formation. The McArras Brook Formation is unconformably overlain by a 120 meter thick Late Viséan clastic sequence of the Martin Road Formation, which represents the oldest rocks deposited in the Merigomish Subbasin. Geochemical and isotopic attributes of representative samples of the clastic rocks in the McArras Brook and Martin Road formations were investigated in order to constrain their respective provenance and to investigate the regional tectonic significance of the angular unconformity that separates them. The clastic rocks selected for analysis have clast sizes ranging from 1 to $4 \mathrm{~mm}$ in diameter. The geochemistry and isotopic signatures of the clastic rocks in these formations are so similar that they are interpreted to have been derived from the same source region. Both formations are characterized by a limited range in $\mathrm{SiO}_{2}(65-78 \mathrm{wt}$. \%), wider ranges in other major elements such as $\mathrm{MgO}$ and $\mathrm{Fe}_{2} \mathrm{O}_{3}$, relatively constant $\mathrm{Ti} / \mathrm{Nb}$, moderate LREE enrichment $\left(\mathrm{La} / \mathrm{Sm}_{\mathrm{n}}=3.6-1.1\right)$, relatively flat $\mathrm{HREE}$ patterns $\left(\mathrm{Tb} / \mathrm{Yb}_{\mathrm{n}}=1.3-1.4\right)$ strongly negative $\varepsilon_{\mathrm{Nd}}$ values $(-6.5$ to -7.7 , calculated for a $320 \mathrm{Ma}$ depositional age), and high $\mathrm{T}_{\mathrm{DM}}$ values (ranging from ca.1.5 to $1.6 \mathrm{Ga}$ ). Taken together, the geochemical and isotopic signature of the McArras Brook and Martin Road formations suggest that they were predominantly derived from local Silurian siliciclastic rocks of the Arisaig Group in the Antigonish Highlands. The isotopic data also suggest an important contribution from the Meguma terrane to the south. The data are compatible with local sources, and the geochemical similarity between the McArras Brook and Martin Road formations suggests that the angular unconformity that separates them is of local, rather than regional, significance.
\end{abstract}

Le sous-bassin de Merigomish longe le flanc méridional du bassin composite du Dévonien tardif-Permien des Maritimes dans les provinces de l'Atlantique. Le sous-bassin est principalement constitué de roches clastiques du Viséen au Westphalien recouvrant des roches clastiques continentales et des basaltes du Dévonien moyen à tardif de la Formation de McArras Brook. La Formation de McArras Brook est recouverte de façon discordante d'une séquence clastique de 120 mètres d'épaisseur du Viséen tardif de la Formation de Martin Road, qui représente les roches les plus âgées s'étant déposées dans le sous-bassin de Merigomish. On a analysé les attributs géochimiques et isotopiques d'échantillons représentatifs des roches clastiques des formations de McArras Brook et de Martin Road pour circonscrire leurs provenances respectives et étudier la portée tectonique régionale de la discordance angulaire les séparant. Les roches clastiques sélectionnées aux fins de l'analyse présentent des clastes donc la taille varie entre un et quatre millimètres de diamètre. Les signatures géochimiques et isotopiques des roches clastiques de ces formations sont tellement similaires qu'on les interprète comme des roches provenant de la même région d'origine. Les deux formations se caractérisent par un écart de valeurs limité de $\mathrm{SiO}_{2}$ (65 à $78 \%$ pds), des écarts de valeurs plus importants des autres principaux éléments comme le $\mathrm{MgO}$ et le $\mathrm{Fe}_{2} \mathrm{O}_{3}$, une teneur relativement constante en $\mathrm{Ti} / \mathrm{Nb}$, un enrichissement modéré en éléments de terres rares légers $\left(\mathrm{La} / \mathrm{Sm}{ }_{n}=\right.$ $3,6-1,1)$, des concentrations relativement stables d'éléments de terres rares lourds $\left(\mathrm{Tb} / \mathrm{Yb} \mathrm{b}_{\mathrm{n}}=1,3-1,4\right)$, des valeurs de $\varepsilon_{\mathrm{Nd}}$ fortement négatives (de $-6,5$ à $-7,7$, d'après un âge de sédimentation de $320 \mathrm{Ma}$ ), et des valeurs de $\mathrm{T}_{\mathrm{DM}}$ élevées (variant entre environ 1,5 et 1,6 Ga). Lorsqu'on les considère ensemble, les signatures géochimiques et isotopiques des formations de McArras Brook et de Martin Road permettent de supposer que le matériel des formations provient principalement de roches silicoclastiques siluriennes du groupe d'Arisaig dans les massifs d'Antigonish. Les données isotopiques évoquent en outre une contribution importante du terrane de Meguma au sud. Les données sont compatibles avec les sources locales et la similarité géochimique entre les formations de McArras Brook et de Martin Road laisse supposer que la discordance angulaire qui les sépare a une portée locale plutôt que régionale.

Traduit par la rédaction 


\section{INTRODUCTION}

The Maritimes Basin of Atlantic Canada is a composite basin comprising several Late Paleozoic depocentres that formed during the latest stages of development of the Appalachian orogen (Williams 1979) The Merigomish Subbasin (Fralick and Schenk 1981) occurs along the southern flank of the Maritimes Basin in a broad northeast-trending trough in eastern Nova Scotia extending from the Antigonish Highlands in the southeast to the Cobequid Highlands in the northwest (Fig. 1). The rocks of the Merigomish Subbasin range from Middle Devonian to Stephanian in age and were deposited during episodes of regional orogenic activity in the Appalachian orogen, i.e., the mid-to-late Devonian Acadian and mid-to-late Carboniferous Alleghenian orogenies. Gibling et al. (1992) showed that regional drainage patterns in the Maritimes Basin were profoundly influenced by orogenic activity and may have resulted in changes in provenance which were linked to specific tectonic events. On a local scale, Stevens et al. (1999) showed that sediment lithogeochemistry and isotopic data can be used to evaluate changing provenance within the Namurian Lismore Formation in the Merigomish Subbasin.

In the Maritimes Basin, basin-fill rocks overstep the boundaries of previously accreted terranes, and consequently may have variable sources from one part of the basin to another. Therefore, in order to investigate the relationship between basin development and regional tectonic activity, the provenance of various sequences deposited in the Maritimes Basin must be determined and compared. Traditional provenance indicators in continental clastic rocks (e.g., paleocurrent directions and clast composition) can provide broad constraints on source regions. Geochemical and isotopic studies, however, provide complementary data that can identify subtle but important contributions from adjoining terranes (La Flèche and Camiré 1996; Feng and Kerrich 1990; Stevens et al. 1999).

\section{REgIONAL SETTING}

\section{Neoproterozoic-Early Devonian basement rocks}

Mainland Nova Scotia is underlain by the Avalon terrane, or Avalonia, in the north, and the Meguma terrane in the south, separated by the Minas Fault Zone (e.g., Keppie 1982, 1993). Avalonian rocks occur along the southeastern flank of the study area in the Antigonish Highlands and to the west of the Merigomish Subbasin in the Cobequid Highlands (Fig. 1). These highlands are predominantly underlain by ca. $630-600$ $\mathrm{Ma}$ arc-related volcanic and sedimentary rocks of the Georgeville Group (Antigonish Highlands) and the broadly correlative Jeffers Group (Cobequid Highlands) and cogenetic plutons.

In the Antigonish Highlands (Fig. 2), the Neoproterozoic rocks are unconformably overlain by Cambrian to Lower Ordovician bimodal volcanic and sedimentary rocks that contain Acado-Baltic fauna. The latter are unconformably overlain by the Late Ordovician to Early Devonian Arisaig
Group (Murphy et al. 1991) that consists of bimodal volcanic rocks overlain by a thick sequence of shallow marine to continental siliciclastic rocks, including the lowermost Silurian Beechill Cove Formation.

To the south, the Meguma terrane consists of Cambrian-Early Ordovician continental rise deposits, overlain by Late Ordovician bimodal volcanic and Siluro-Devonian shallow marine rocks that pass upwards into continental deposits of Early-Middle Devonian age (e.g., Schenk 1991). These rocks were intruded by voluminous $380-370$ Ma granitoid batholiths and coeval lamprophyric dykes and mafic gneisses (Clarke et al. 1997).

\section{Middle Devonian-Carboniferous rocks}

Basin development in Atlantic Canada began in Middle to Late Devonian during the waning stages of the Acadian orogeny (Bradley 1982; Donohoe and Wallace 1985; Yeo and Ruixiang 1986, 1987; Nance 1987; McCutcheon and Robinson 1987; Ryan et al. 1987; Ryan and Boehner 1994), which is associated with dextral transpression between the Avalon and Meguma terranes (e.g., Keppie 1993).

In the northern Antigonish Highlands, the Arisaig Group is unconformably overlain by interbedded mafic flows, conglomerate and sandstone of the Middle to Late Devonian McArras Brook Formation (Murphy et al. 1991). Sandstones and conglomerate in the McArras Brook Formation occur between basaltic flows and contain abundant basaltic clasts at the base of individual beds. The central portions of the beds contain clasts of siltstone, slate and quartz, minor granite, basalt and feldspar in a matrix dominated by hematite and clay minerals.

In the Cobequid Highlands, Neoproterozoic and Early Paleozoic rocks are unconformably overlain by voluminous ca. $360 \mathrm{Ma}$ bimodal volcanic rocks and interbedded continental clastic rocks (Fountain Lake Group and correlatives) and coeval granitoid and gabbroic plutonic rocks (Donohoe and Wallace 1985; Pe-Piper et al. 1989; Pe-Piper and Piper 1998; Murphy et al. 2001).

In the Late Devonian-Early Carboniferous, continental clastic rocks of the Horton Group were deposited in a series of rift basins (McCutcheon and Robinson 1987; Martel and Gibling 1991) that overstepped the Avalon-Meguma terrane boundary. The clastic rocks were locally derived from adjacent highland areas (Hamblin and Rust 1989; Gibling 1995; Murphy et al. 1995; Murphy 2000). During the Viséan, a marine incursion resulted in regionally extensive deposition of limestone, evaporitic, and clastic rocks of the Windsor Group under hot semi-arid to arid conditions (Ryan and Boehner 1994; Chandler 1997). Within the Merigomish Subbasin, the Windsor Group is divided into continental clastic rocks of the Martin Road Formation overlain by laminated limestone of the Ardness Formation.

In the study area, the Martin Road Formation lies unconformably on the McArras Brook Formation and consists of ca. $120 \mathrm{~m}$ of fining-upwards redbeds (Keppie et al. 1978). The base of the sequence includes planar-bedded sandstone with abundant basaltic clasts, and interbedded red siltstone and pebble conglomerate containing plant fragments. The upper 


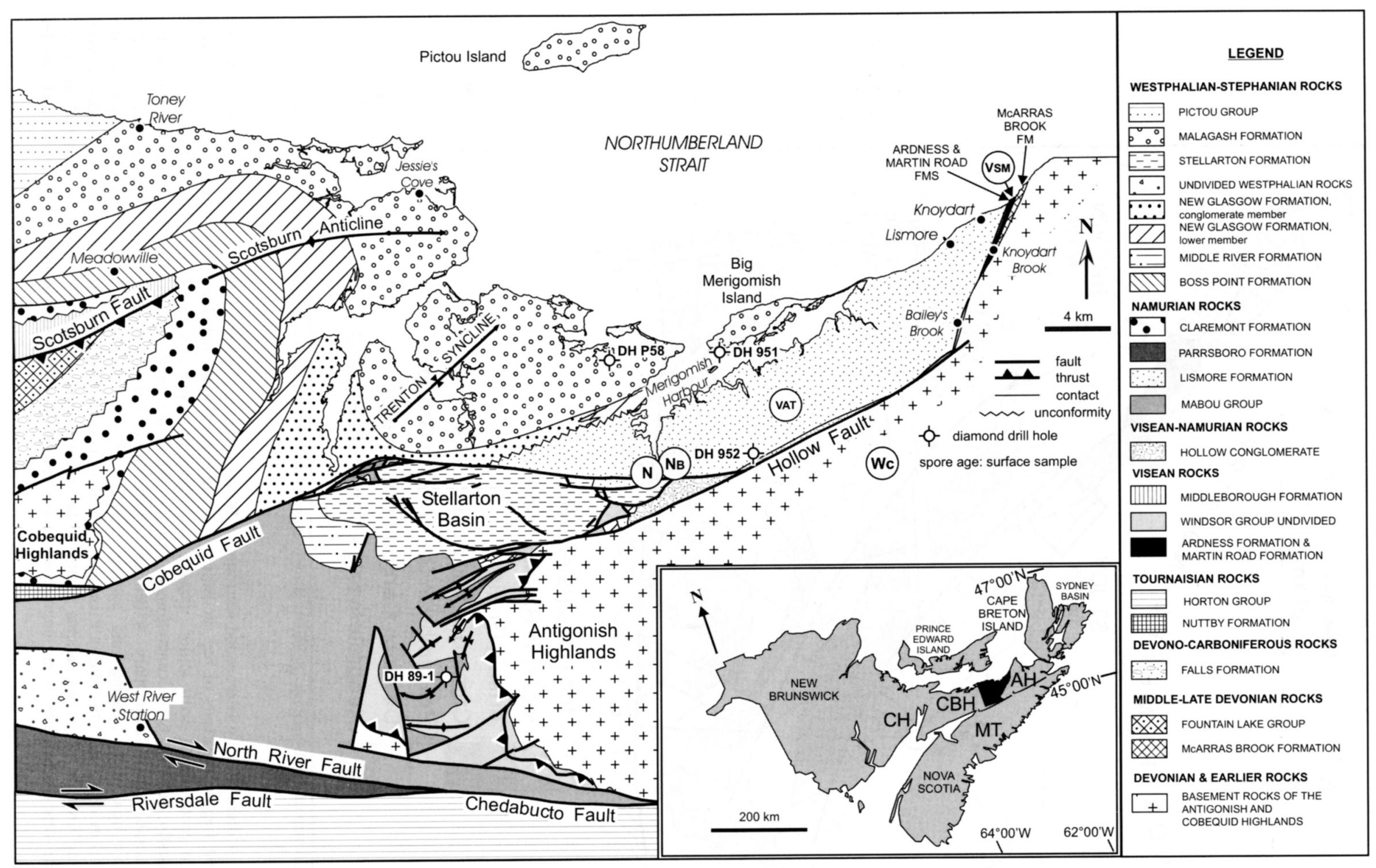

Fig. 1. Summary geological map (after Chandler et al. 1997; Stevens et al. 1999) of the Merigomish Subbasin study area within the Maritimes Basin (inset) between the Antigonish Highlands (AH) and the Cobequid Highlands (CBH). $\mathrm{CH}$, Caledonian Highlands; MT, Meguma terrane. 


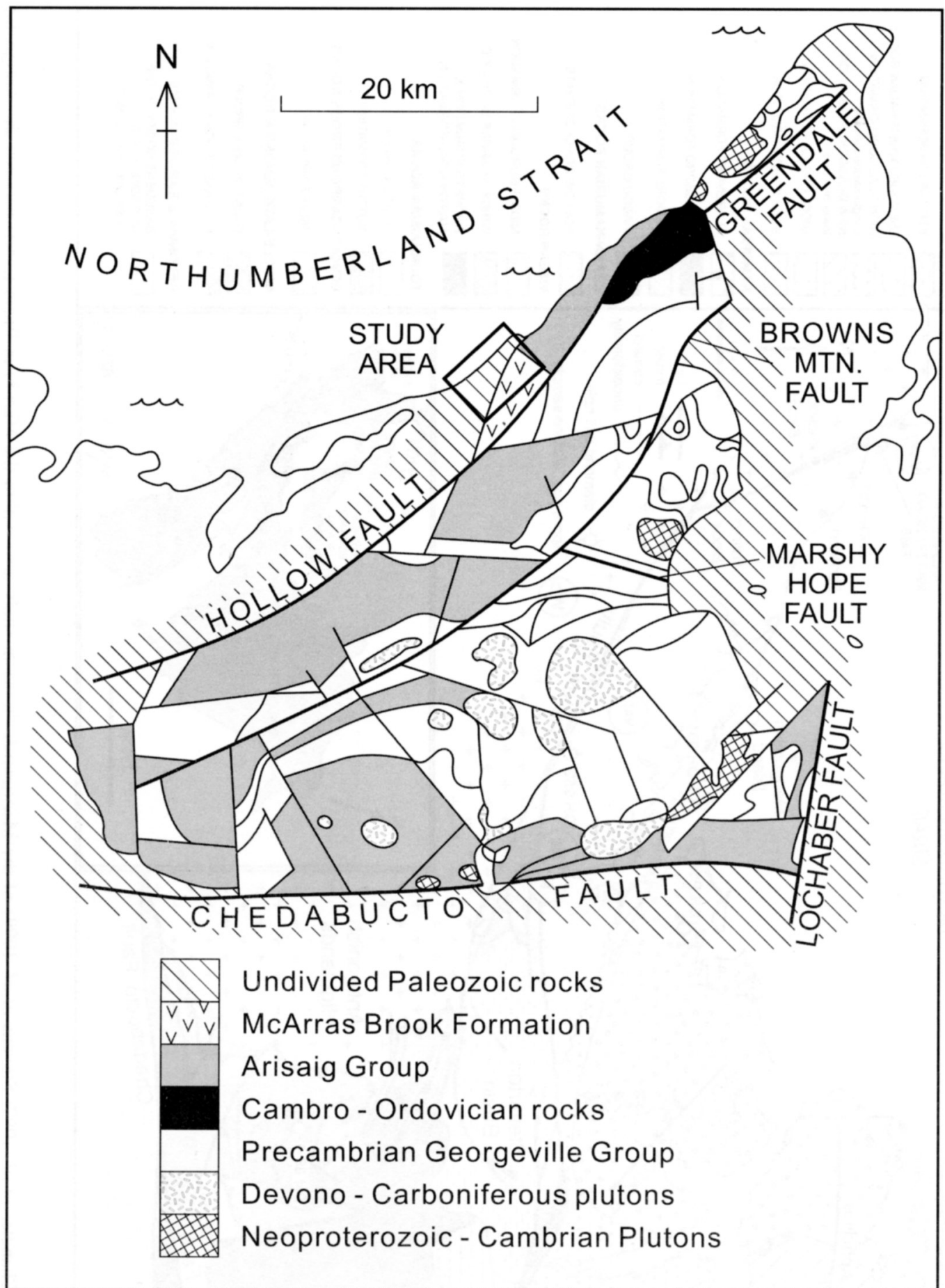

Fig. 2. Summary geological map of the Antigonish Highlands (after Murphy et al. 1991 and surrounding areas (Boucot et al. 1974). The study area is shown in the rectangle.

portion of the sequence is dominated by interbedded siltstone and mudstone with plant fragments. Clasts of red sandstone and calcareous siltstone predominate, with minor, granite, quartz, and feldspar. Locally, there are barite concretions and lenses of copper mineralization. Sedimentary structures include ripple marks, trough cross bedding and parting lineations. Paleontological evidence from the Martin Road and the conformably overlying Ardness formations indicate a Late Viséan age, close to the depositional age of the uppermost
Windsor Group. Spores in plant fragments within the Martin Road Formation are dated as Viséan SM, and in the overlying Ardness limestone as Viséan C to E1 (after Utting 1987).

Along the southern flank of the Merigomish Subbasin, the Late Viséan-Early Namurian Hollow Conglomerate (Chandler et al. 1997) is considered to be the basal member of the Mabou Group. This unit was deposited as a braided alluvial fan (Fralick and Schenk 1981) and is attributed to coeval movement along the basin-bounding Hollow Fault (Chandler 
1998). This was followed by deposition of $2500 \mathrm{~m}$ of upwardcoarsening continental clastic rocks of the Lismore Formation (Fralick 1980; Chandler et al. 1997). Spore samples from the Lismore Formation redbeds directly overlying the Ardness limestone also suggest a Late Viséan age (Viséan AT; after Utting 1987), whereas further up-section, the Lismore Formation has yielded Early Namurian and Namurian B spore assemblages (Chandler et al. 1997).

The Lismore Formation is unconformably overlain by the Westphalian-Stephanian Pictou Group which consists of conglomerate, sandstone and red cross- to planar-bedded sandstone of the New Glasgow Formation, overlain by the Malagash Formation, which consists of interbedded fluvial sandstone and mudstone (Naylor et al. 1989; Chandler et al. 1997; Chandler 1998).

\section{GEOCHEMISTRY}

In order to understand the tectonic evolution of the Maritimes Basin, the ongoing relationship between basin development and basin fill must be determined in each subbasin. This is especially important along the basin margins where tectonic activity along basin-margin faults has been documented (Chandler et al. 1997; Miller et al. 1995; Waldron et al. 1997). This activity is associated with the development of an angular unconformity between the McArras Brook and Martin Road formations, exposed along a coastal section about $600 \mathrm{~m}$ east of Knoydart Point (Keppie et al. 1978). Recent studies (e.g., Stevens et al. 1999, Murphy 2000) have shown a relationship between tectonic activity and changes in provenance at various stages of basin development, suggesting that an evaluation of the provenance of the clastic rocks of the McArras Brook and Martin Road formations may provide insights into the tectonic significance of the unconformity.

To date, provenance studies in the rocks of the Maritimes Basin have focused on sedimentological and petrographic aspects of the clastic rocks (e.g., Yeo and Ruixiang 1986; Ryan et al. 1987; Gibling et al. 1992). However, geochemical and isotopic characteristics of the basin may also aid in indicating the relative contributions from adjacent terranes, and help establish the sediment sink for denuded basement rocks (Bhatia and Crook 1986; McLennan et al. 1993). Relatively insoluble high field strength (HFS), REE, trace element ratios, and $\mathrm{Nd}$ isotopic signatures are most useful in these studies, as they are less affected by secondary processes such as weathering and diagenesis (Holland 1978; Nelson and DePaolo 1988; McLennan et al. 1993).

\section{Methodology}

In order to compare the provenance of the McArras Brook and Martin Road formations, 18 samples, 7 from the McArras Brook Formation (coarse sandstone to conglomerate) and 11 from the Martin Road Formation (4 conglomerate, 6 sandstone, 1 siltstone) were analyzed (Table 1). The conglomerate samples selected for analysis have maximum grain size of $5 \mathrm{~mm}$. The McArras Brook Formation samples were taken from along McArras Brook, and the shoreline to the southwest of the brook. Martin Road Formation samples were taken from the shoreline section above the contact with the McArras Brook Formation, and below the contact with the Ardness limestone at Knoydart Point. Major and trace element analyses were performed by X-ray fluorescence at the Nova Scotia Regional Geochemical Centre, at St. Mary's University, Halifax, Nova Scotia and the Department of Geology, at Université d'Ottawa, Ottawa, Ontario, using a Philips PW 2400 sequential spectrometer. In both laboratories, analytical precision is better than $5 \%$ for major and minor element oxides and approximately $5 \%$ for trace elements, except for lead and thorium, which are slightly higher, and for barium, which is $10 \%$.

Seven representative samples ( 3 from the McArras Brook Formation, 4 from the Martin Road Formation) were analyzed for REE, Hf, and Ta (Table 1), by inductively coupled mass spectrometry, and for Sm-Nd isotopic compositions (Table 2) at the AURIF (Atlantic Universities Regional Isotope Facility) at Memorial University, Newfoundland.

The precision and accuracy of the REE analyses is about $10 \%$. Analytical procedures for the rare earth and isotopic analyses at AURIF are given in Longerich et al. (1990). Procedures for the $\mathrm{Sm}$ and $\mathrm{Nd}$ isotope data (Table 2) were as follows. The ${ }^{143} \mathrm{Nd} /{ }^{144} \mathrm{Nd}$ ratios were measured by thermal ionization mass spectrometry, after chemical separation of $\mathrm{Nd}$ from Sm and other REE by ion-exchange chemistry. La Jolla $\mathrm{Nd}$ standard gave an average value of $0.511862 \pm 0.000016$. $\varepsilon_{\mathrm{Nd}}$ values are relative to ${ }^{143} \mathrm{Nd} /{ }^{144} \mathrm{Nd}=0.512638$ and ${ }^{147} \mathrm{Sm} /{ }^{144} \mathrm{Nd}=0.196593$ for present day CHUR (Jacobsen and Wasserburg 1980) and $\lambda^{147} \mathrm{Sm}=6.54 \times 10^{-12} /$ year. $\mathrm{T}_{\mathrm{DM}}$ ages are calculated using the model of DePaolo $(1981,1988)$. The ${ }^{143} \mathrm{Nd} /{ }^{144} \mathrm{Nd}$ errors are reported at the $95 \%$ confidence level $(2 \sigma)$ and are based solely on mass spectrometry measurements. The ${ }^{147} \mathrm{Sm} /{ }^{144} \mathrm{Nd}$ ratios are calculated with data reduction software created at Memorial University using LOTUS 123 97. The calculations are based on measured ${ }^{147} \mathrm{Sm} /{ }^{149} \mathrm{Sm}$ and ${ }^{150} \mathrm{Nd} /{ }^{144} \mathrm{Nd}$ spiked ratios. The ${ }^{147} \mathrm{Sm} /{ }^{144} \mathrm{Nd}$ reported errors are absolute $2 \sigma$ and are quadratically added using the $2 \sigma$ errors for ${ }^{147} \mathrm{Sm} /{ }^{149} \mathrm{Sm}$ and ${ }^{150} \mathrm{Nd} /{ }^{144} \mathrm{Nd}$ measured isotopic ratios.

\section{ReSUlts}

In general, the clastic rocks of both formations show negative correlations between most major element oxides and $\mathrm{SiO}_{2}$ (Fig. 3). The McArras Brook Formation clastic rocks have more restricted ranges in major element chemistry. For example, in the McArras Brook Formation, $\mathrm{SiO}_{2}$ ranges from 66.9 to 71.5 wt. $\%, \mathrm{Al}_{2} \mathrm{O}_{3}$ from 10.6 to 15.7 wt. $\%$, and $\mathrm{Fe}_{2} \mathrm{O}_{3}$ from 4.9 to $7.4 \mathrm{wt}$ \% compared to the Martin Road Formation (65.2-78.1 wt. $\% \mathrm{SiO}_{2}, 7.7-17.2$ wt. $\% \mathrm{Al}_{2} \mathrm{O}_{3}$, and 2.2-6.3 wt. $\left.\% \mathrm{Fe}_{2} \mathrm{O}_{3}\right)$. The sandstone samples have an average $\mathrm{K} / \mathrm{Rb}=$ 241 , a value which is consistent with typical continental crust (Taylor and McLennan 1985).

In quartz-rich rocks, the trace element and isotopic signature is profoundly influenced by accessory and clay minerals. Insoluble trace elements and trace element ratios were used to characterize the geochemical signature and provenance of the Martin Road Formation (see Bhatia and 
Table 1. Geochemical analyses of the McArras and Martin Road Formation samples

\begin{tabular}{|c|c|c|c|c|c|c|c|c|c|c|c|c|c|c|c|c|c|c|}
\hline $\begin{array}{l}\text { Sample } \\
\text { Formation } \\
\text { Lithology }\end{array}$ & $\begin{array}{l}\mathrm{J} 040 \\
\mathrm{MA}\end{array}$ & $\begin{array}{l}\mathrm{J} 041 \\
\mathrm{MA}\end{array}$ & $\begin{array}{l}\mathrm{J} 042 \\
\mathrm{MA}\end{array}$ & $\begin{array}{l}\mathrm{J} 043 \\
\mathrm{MA}\end{array}$ & $\begin{array}{c}\mathrm{J} 044 \\
\mathrm{MA}\end{array}$ & $\begin{array}{l}\mathrm{J} 045 \\
\mathrm{MA}\end{array}$ & $\begin{array}{l}\mathrm{J} 046 \\
\mathrm{MA}\end{array}$ & $\begin{array}{c}\mathrm{J} 022 \\
\mathrm{MR} \\
\text { sst }\end{array}$ & $\begin{array}{l}\mathrm{J} 024 \\
\mathrm{MR} \\
\text { cong }\end{array}$ & $\begin{array}{c}\mathrm{J} 026 \\
\mathrm{MR} \\
\text { sst }\end{array}$ & $\begin{array}{c}\mathrm{J} 027 \\
\mathrm{MR} \\
\text { sst }\end{array}$ & $\begin{array}{c}\text { J029 } \\
\text { MR } \\
\text { sst }\end{array}$ & $\begin{array}{c}\text { J030 } \\
\text { MR } \\
\text { sst }\end{array}$ & $\begin{array}{l}\mathrm{J} 031 \\
\mathrm{MR} \\
\text { cong }\end{array}$ & $\begin{array}{c}\text { J032 } \\
\text { MR } \\
\text { sst }\end{array}$ & $\begin{array}{c}\mathrm{J} 033 \\
\text { MR } \\
\text { silt }\end{array}$ & $\begin{array}{l}\mathrm{J} 035 \\
\mathrm{MR} \\
\text { cong }\end{array}$ & $\begin{array}{c}\mathrm{J} 037 \\
\mathrm{MR} \\
\text { cong }\end{array}$ \\
\hline $\mathrm{SiO}_{2}$ & 70.98 & 71.11 & 68.22 & 66.90 & 69.74 & 71.49 & 71.24 & 76.95 & 67.58 & 73.24 & 77.80 & 71.34 & 78.11 & 70.51 & 75.58 & 65.26 & 70.18 & 70.16 \\
\hline $\mathrm{Fe}_{2} \mathrm{O}_{3}$ & 4.90 & 6.26 & 5.70 & 6.27 & 7.46 & 5.33 & 6.09 & 3.68 & 6.24 & 4.47 & 4.18 & 2.27 & 2.58 & 4.66 & 3.76 & 5.21 & 4.74 & 5.95 \\
\hline $\mathrm{MgO}$ & 1.86 & 2.08 & 1.89 & 1.87 & 1.97 & 1.62 & 1.73 & 1.26 & 2.01 & 1.49 & 1.43 & 1.16 & 1.10 & 2.24 & 1.80 & 2.63 & 2.08 & 2.64 \\
\hline $\mathrm{CaO}$ & 8.86 & 2.75 & 11.10 & 10.08 & 0.86 & 1.80 & 4.22 & 6.00 & 4.14 & 4.61 & 3.36 & 4.58 & 6.38 & 3.60 & 4.81 & 4.22 & 6.20 & 1.81 \\
\hline $\mathrm{Na}_{2} \mathrm{O}$ & 0.98 & 0.65 & 1.10 & 1.21 & 0.96 & 1.15 & 1.04 & 1.15 & 1.18 & 1.08 & 1.36 & 0.95 & 1.12 & 1.00 & 1.36 & 0.75 & 1.50 & 1.30 \\
\hline $\mathrm{TiO}_{2}$ & 0.79 & 0.80 & 0.69 & 0.79 & 0.96 & 0.96 & 0.90 & 0.72 & 0.87 & 0.95 & 0.70 & 0.70 & 0.68 & 0.92 & 0.66 & 0.97 & 0.78 & 0.80 \\
\hline $\mathrm{MnO}$ & 0.17 & 0.12 & 0.14 & 0.10 & 0.06 & 0.06 & 0.10 & 0.26 & 0.19 & 0.22 & 0.17 & 0.19 & 0.24 & 0.13 & 0.15 & 0.16 & 0.13 & 0.07 \\
\hline $\mathrm{P}_{2} \mathrm{O}_{5}$ & 0.09 & 0.07 & 0.09 & 0.08 & 0.10 & 0.10 & 0.08 & 0.10 & 0.16 & 0.13 & 0.11 & 0.11 & 0.11 & 0.14 & 0.12 & 0.15 & 0.11 & 0.07 \\
\hline L.O.I. & 8.40 & 5.90 & 11.10 & 9.30 & 4.20 & 4.10 & 6.20 & 6.20 & 6.20 & 5.60 & 4.80 & 5.30 & 5.70 & 6.30 & 5.80 & 6.90 & 6.80 & 4.80 \\
\hline TOTAL & 101.23 & 98.30 & 101.88 & 101.99 & 100.80 & 97.91 & 101.50 & 100.08 & 100.24 & 99.90 & 99.73 & 92.15 & 99.47 & 100.61 & 100.91 & 100.70 & 99.96 & 99.36 \\
\hline \multicolumn{19}{|c|}{ Trace elements by XRF (ppm) } \\
\hline $\mathrm{Ba}$ & 326 & 437 & 344 & 504 & 530 & 383 & 411 & 2680 & 2673 & 2428 & 1400 & 33160 & 621 & 289 & 867 & 939 & 5002 & 1646 \\
\hline $\mathrm{Rb}$ & 72 & 88 & 62 & 76 & 115 & 94 & 96 & 64 & 65 & 90 & 60 & 63 & 42 & 110 & 63 & 142 & 75 & 101 \\
\hline $\mathrm{Sr}$ & 101 & 71 & 93 & 90 & 90 & 84 & 97 & 118 & 119 & 113 & 77 & 934 & 56 & 70 & 83 & 79 & 182 & 98 \\
\hline $\mathrm{Zr}$ & 312 & 274 & 193 & 214 & 234 & 330 & 258 & 422 & 424 & 558 & 308 & 394 & 450 & 360 & 231 & 268 & 269 & 280 \\
\hline $\mathrm{Nb}$ & 12 & 11 & 10 & 13 & 18 & 15 & 15 & 12 & 13 & 16 & 12 & 13 & 12 & 15 & 13 & 16 & 12 & 14 \\
\hline $\mathrm{Pb}$ & 26 & 42 & 13 & 13 & 15 & 20 & 16 & b.d. & b.d. & 48 & b.d. & 16 & 18 & b.d. & b.d. & 247 & 12 & 29 \\
\hline $\mathrm{Ga}$ & 12 & 12 & 12 & 13 & 20 & 16 & 16 & 9 & 8 & 12 & 8 & 10 & 8 & 17 & 12 & 21 & 15 & 15 \\
\hline $\mathrm{Zn}$ & 105 & 126 & 83 & 74 & 81 & 70 & 67 & 51 & 47 & 72 & 65 & 59 & 163 & 109 & 79 & 115 & 79 & 157 \\
\hline $\mathrm{Cu}$ & 15 & 8 & 17 & 20 & 19 & 19 & 17 & b.d. & 6 & 10 & 5 & 14 & 1575 & 36 & 53 & 281 & 11 & 17 \\
\hline $\mathrm{Ni}$ & 33 & 21 & 36 & 38 & 49 & 37 & 39 & 21 & 23 & 33 & 23 & 24 & 19 & 40 & 30 & 48 & 39 & 45 \\
\hline V & 221 & 71 & 90 & 99 & 141 & 110 & 147 & 67 & 65 & 85 & 67 & 28 & 50 & 112 & 75 & 129 & 78 & 117 \\
\hline $\mathrm{Cr}$ & 81 & 63 & 68 & 84 & 111 & 103 & 98 & 67 & 70 & 92 & 81 & 58 & 63 & 104 & 74 & 110 & 99 & 112 \\
\hline $\mathrm{Th}^{*}$ & n.d. & 10 & n.d. & 11 & 13 & n.d. & n.d. & n.d. & 11 & 10 & n.d. & n.d. & n.d. & 13 & n.d. & n.d. & n.d. & 12 \\
\hline \multicolumn{19}{|c|}{ REE and other trace elements by ICPMS (ppm) except as indicated. } \\
\hline $\mathrm{La}$ & 46.99 & n.d. & n.d. & n.d. & n.d. & 64.43 & 39.84 & 27.32 & n.d. & n.d. & 25.55 & 25.31 & n.d. & n.d. & n.d. & 49.24 & n.d. & n.d. \\
\hline $\mathrm{Ce}$ & 209.55 & n.d. & n.d. & n.d. & n.d. & 143.15 & 80.03 & 58.77 & n.d. & n.d. & 53.69 & 56.18 & n.d. & n.d. & n.d. & 100.77 & n.d. & n.d. \\
\hline $\operatorname{Pr}$ & 26.83 & n.d. & n.d. & n.d. & n.d. & 15.60 & 9.75 & 7.34 & n.d. & n.d. & 6.48 & 7.57 & n.d. & n.d. & n.d. & 11.96 & n.d. & n.d. \\
\hline $\mathrm{Nd}$ & 119.17 & n.d. & n.d. & n.d. & n.d. & 58.09 & 37.21 & 29.59 & n.d. & n.d. & 25.17 & 33.34 & n.d. & n.d. & n.d. & 46.00 & n.d. & n.d. \\
\hline Sm & 26.35 & n.d. & n.d. & n.d. & n.d. & 11.26 & 8.17 & 6.70 & n.d. & n.d. & 5.30 & 8.24 & n.d. & n.d. & n.d. & 9.20 & n.d. & n.d. \\
\hline $\mathrm{Eu}$ & 4.74 & n.d. & n.d. & n.d. & n.d. & 2.06 & 1.66 & 1.39 & n.d. & n.d. & 1.06 & 3.38 & n.d. & n.d. & n.d. & 1.90 & n.d. & n.d. \\
\hline $\mathrm{Gd}$ & 16.49 & n.d. & n.d. & n.d. & n.d. & 7.84 & 6.60 & 5.75 & n.d. & n.d. & 4.49 & 7.05 & n.d. & n.d. & n.d. & 7.92 & n.d. & n.d. \\
\hline $\mathrm{Tb}$ & 1.85 & n.d. & n.d. & n.d. & n.d. & 1.07 & 0.96 & 0.88 & n.d. & n.d. & 0.71 & 1.00 & n.d. & n.d. & n.d. & 1.18 & n.d. & n.d. \\
\hline $\mathrm{Tm}$ & 0.49 & n.d. & n.d. & n.d. & n.d. & 0.51 & 0.47 & 0.44 & n.d. & n.d. & 0.35 & 0.47 & n.d. & n.d. & n.d. & 0.54 & n.d. & n.d. \\
\hline $\mathrm{Yb}$ & 2.99 & n.d. & n.d. & n.d. & n.d. & 3.25 & 2.94 & 2.89 & n.d. & n.d. & 2.37 & 2.94 & n.d. & n.d. & n.d. & 3.45 & n.d. & n.d. \\
\hline $\mathrm{Lu}$ & 0.48 & n.d. & n.d. & n.d. & n.d. & 0.53 & 0.48 & 0.45 & n.d. & n.d. & 0.35 & 0.45 & n.d. & n.d. & n.d. & 0.52 & n.d. & n.d. \\
\hline $\mathrm{Hf}$ & 11.97 & n.d. & n.d. & n.d. & n.d. & 10.15 & 8.37 & 11.05 & n.d. & n.d. & 7.17 & 10.14 & n.d. & n.d. & n.d. & 6.72 & n.d. & n.d. \\
\hline $\mathrm{Ta}$ & 1.18 & n.d. & n.d. & n.d. & n.d. & 1.32 & 1.18 & 0.91 & n.d. & n.d. & 0.58 & 1.28 & n.d. & n.d. & n.d. & 1.05 & n.d. & n.d. \\
\hline $\mathrm{Th}^{*}$ & 9.64 & n.d. & n.d. & n.d. & n.d. & 11.58 & 10.69 & 8.35 & n.d. & n.d. & 7.82 & 7.57 & n.d. & n.d. & n.d. & 11.10 & n.d. & n.d. \\
\hline
\end{tabular}

Notes: * Th analysed by XRF and ICP-MS for different samples. b.d. $=$ below detection, $n$.d. $=$ not determined 
Table 2. Sm and Nd isotope compositions of samples from the Martin Road and McArras Brook formations.

\begin{tabular}{|c|c|c|c|c|c|c|c|}
\hline \multirow[b]{2}{*}{ Sample } & \multirow[b]{2}{*}{ Sm (ppm) } & \multirow[b]{2}{*}{$\mathrm{Nd}(\mathrm{ppm})$} & \multicolumn{2}{|c|}{ measured } & \multirow[b]{2}{*}{$\begin{array}{l}\text { Age } \\
(\mathrm{Ma})\end{array}$} & \multirow[b]{2}{*}{$\begin{array}{c}\varepsilon_{N d} \\
(U R) .\end{array}$} & \multirow[b]{2}{*}{$\begin{array}{l}\mathrm{T}_{D M} \\
(\mathrm{Ga}) \\
\end{array}$} \\
\hline & & & $\frac{{ }^{147} \mathrm{Sm}}{{ }^{144} \mathrm{Nd}}$ & $\frac{{ }^{143} \mathrm{Nd}}{{ }^{144} \mathrm{Nd}}$ & & & \\
\hline \multicolumn{8}{|c|}{ Martin Road Formation } \\
\hline $\mathrm{J} 022$ & 6.70 & 29.59 & 0.12423 & 0.512126 & 320 & -7.0 & 1428 \\
\hline $\mathrm{J} 027$ & 5.30 & 25.17 & 0.11821 & 0.512139 & 320 & -6.5 & 1354 \\
\hline J029 & 8.24 & 33.34 & 0.14943 & 0.512179 & 320 & -7.0 & 1679 \\
\hline $\mathrm{J} 033$ & 9.29 & 46.00 & 0.12478 & 0.512099 & 320 & -7.6 & 1465 \\
\hline \multicolumn{8}{|c|}{ McArras Brook Formation } \\
\hline $\mathrm{J} 040$ & 27.45 & 122.89 & $0.13789(02)$ & 0.512138 & 360 & 0.3 & 1573 \\
\hline J045 & 11.68 & 58.26 & $0.12381(11)$ & 0.512074 & 360 & -2.0 & 1481 \\
\hline $\mathrm{J} 046$ & 8.62 & 41.06 & $0.12966(05)$ & 0.512089 & 360 & -1.8 & 1531 \\
\hline
\end{tabular}

Crook 1986; McLennan et al. 1993) based on its accessory and clay mineral content. These methods help determine the provenance of these minerals, rather than the provenance of the quartz. Although the absolute abundance of each of these elements may be affected by accumulation or fractionation of heavy minerals during transport and deposition, inter-element ratios between these elements are generally not affected. On plots of $\mathrm{Ti} / \mathrm{Nb}$ vs. $\mathrm{Zr} / \mathrm{Nb}, \mathrm{Zr} / \mathrm{V}$ and $\mathrm{Zr} / \mathrm{Y}$ (Figs. $4 \mathrm{a}-\mathrm{c}$ ), the McArras Brook and Martin Road samples show similar characteristics. Both suites have similar and relatively constant $\mathrm{Ti} / \mathrm{Nb}$. The McArras Brook Formation has a more limited range in $\mathrm{Zr} / \mathrm{Nb}, \mathrm{Zr} / \mathrm{Y}$ and $\mathrm{Zr} / \mathrm{V}$ than the Martin Road Formation. The clastic rocks in both formations show a strong positive correlation between $\mathrm{Ti} / \mathrm{V}$ and $\mathrm{Zr} / \mathrm{V}$, and a weaker correlation between $\mathrm{Ti} / \mathrm{V}$ and $\mathrm{Zr} / \mathrm{Y}$ (Figs. $5 \mathrm{a}, \mathrm{b}$ ).

Chondrite-normalized REE values for the McArras Brook and Martin Road samples show moderate LREE enrichment $\left(\mathrm{La} / \mathrm{Sm}_{\mathrm{n}}=3.6-1.1\right)$ and relatively flat HREE patterns $\left(\mathrm{Tb} / \mathrm{Yb}_{\mathrm{n}}\right.$ $=1.3-1.4)$. Two of the three McArras Brook samples and three of four Martin Road samples display slight negative Eu anomalies, whereas one Martin Road sample displays a positive Eu anomaly (Figs. 6a, b).

$\mathrm{Sm}-\mathrm{Nd}$ isotopic data in clastic rocks are thought to represent the weighted average of $\varepsilon_{\mathrm{Nd}}$ values of REE-bearing minerals and rock fragments from the source area (Nelson and DePaolo 1988). Both formations are characterized by strongly negative $\varepsilon_{N_{d}}$ values ranging from -7.1 to -7.7 in the McArras Brook Formation (calculated for a 360 Ma depositional age) from -6.5 to -7.7 for the Martin Road Formation (calculated for a $320 \mathrm{Ma}$ depositional age). $\mathrm{T}_{\mathrm{DM}}$ values are also similar, ranging from ca. 1.5 to $1.6 \mathrm{Ga}$ in the McArras Brook Formation and from 1.4 to $1.7 \mathrm{Ga}$ in the Martin Road Formation (Fig. 7, Table 2).

\section{COMPARISON WITH POTENTIAL SOURCE AREAS}

\section{Possible source regions}

Given the location of the study area, there are several possible source areas for the clastic rocks of the McArras Brook and Martin Road formations. They include the underlying Antigonish Highlands basement rocks that occur along the southern and eastern flanks of the Merigomish Subbasin, the Cobequid and Caledonian Highlands to the west, and the Meguma terrane to the south. In the Antigonish
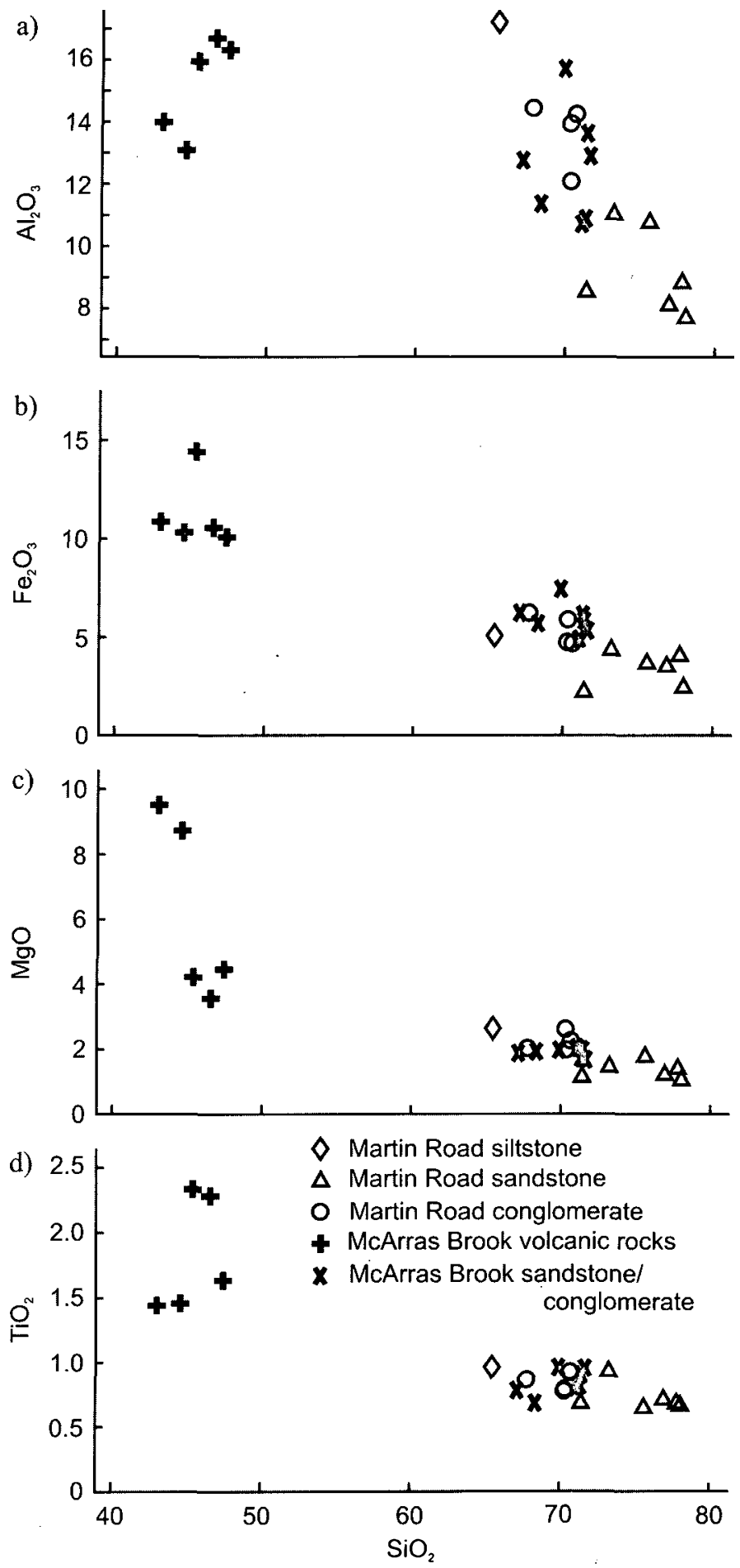

Fig. 3. Variations in selected major element oxides with $\mathrm{SiO}_{2}$ for the McArras Brook and Martin Road formations. (a) $\mathrm{SiO}_{2}$ vs. $\mathrm{Al}_{2} \mathrm{O}_{3}$, (b) $\mathrm{SiO}_{2}$ vs. $\mathrm{Fe}_{2} \mathrm{O}_{3}$, (c) $\mathrm{SiO}_{2}$ vs. $\mathrm{MgO}$, (d) $\mathrm{SiO}_{2}$ vs. $\mathrm{TiO}_{2}$.

Highlands, the geochemistry of the Georgeville Group clastic rocks is representative of the Neoproterozoic rocks as the geochemical signature is attributed to mixing of coeval mafic and felsic arc-related volcanic rocks (Murphy and MacDonald 1993). The geochemistry of the Early Silurian Beechill Cove Formation is typical of the sedimentary rocks of the Silurian Arisaig Group (Murphy et al. 1995; Murphy, unpublished 

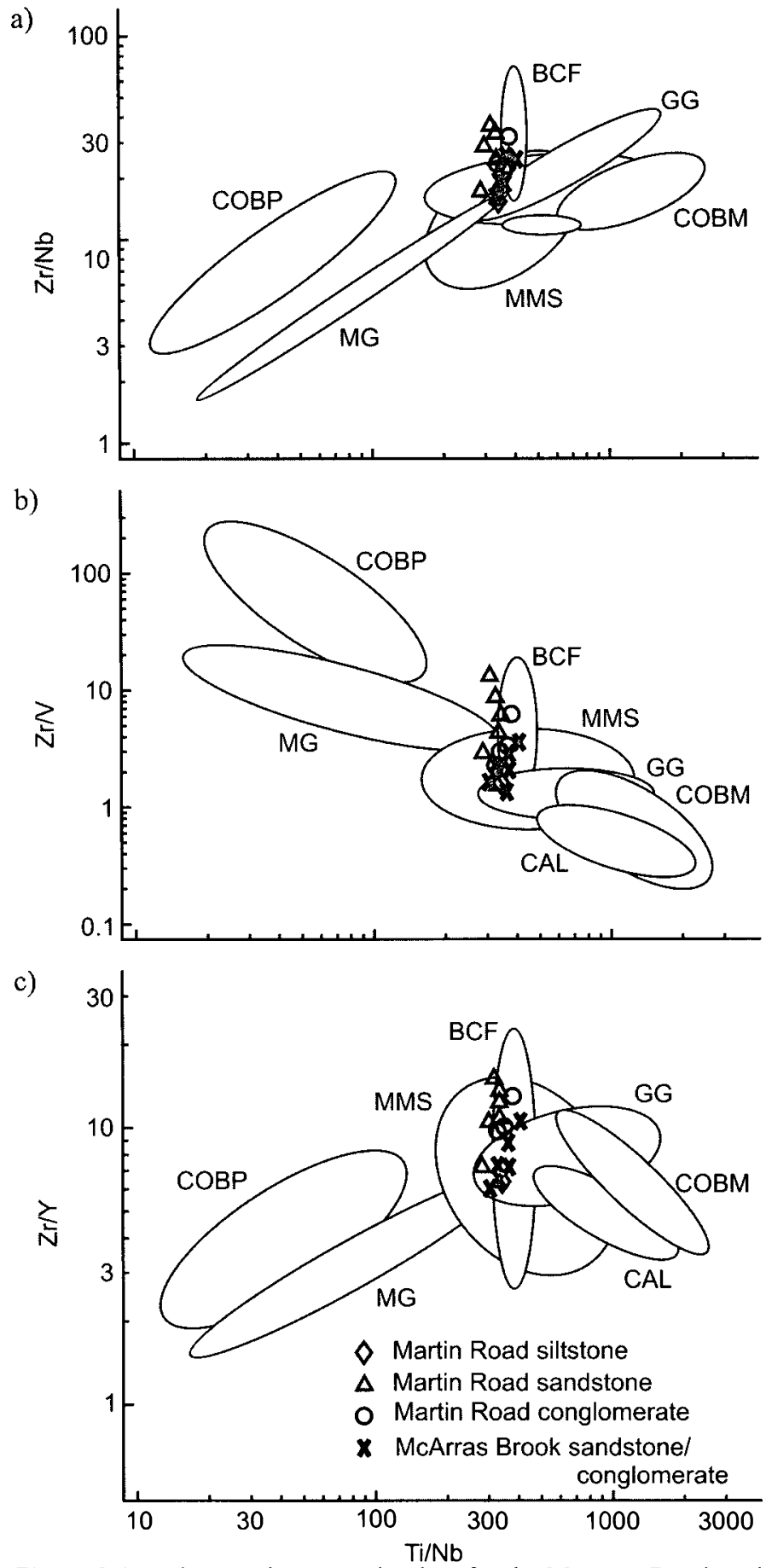

Fig. 4. Selected trace element ratio plots for the McArras Brook and Martin Road formations. a) $\mathrm{Ti} / \mathrm{Nb}$ vs. $\mathrm{Zr} / \mathrm{Nb}$; b) $\mathrm{Ti} / \mathrm{Nb}$ vs. $\mathrm{Zr} / \mathrm{V}$; c) $\mathrm{Ti} / \mathrm{Nb}$ vs. $\mathrm{Zr} / \mathrm{Y}$. For comparison purposes, fields outlining the geochemistry of adjacent basement rocks are shown. BCF, Beechill Cove Formation (Murphy et al. 1995); GG, Georgeville Group (Murphy and MacDonald 1993); COBP, Late Devonian Cobequid Highlands granitic plutons (Pe-Piper et al. 1989); MG, Meguma terrane Late Devonian granite plutons (Clarke et al. 1988; Ham et al. 1989); COBM, Middle to Late Devonian Cobequid Highlands mafic plutonic and volcanic rocks (Pe-Piper et al. 1989; Pe-Piper and Piper, 1998); CAL. Caledonian Highlands mafic rocks (Barr 1987); MMS, Meguma Group metasedimentary rocks (J. Dostal, personal communication, 1997).
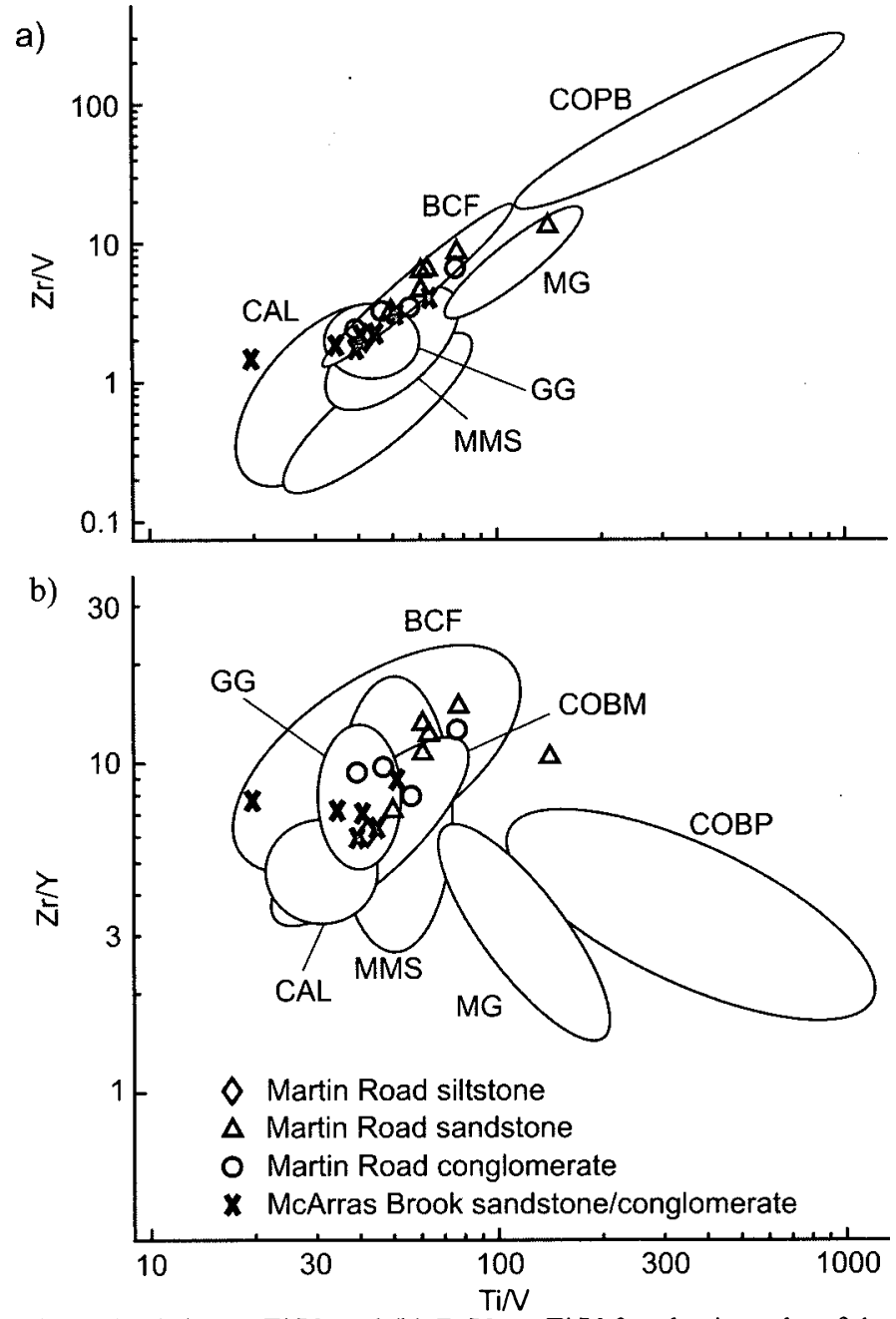

Fig. 5. (a) $\mathrm{Zr} / \mathrm{V}$ vs. $\mathrm{Ti} / \mathrm{V}$, and (b) $\mathrm{Zr} / \mathrm{Y}$ vs. Ti/V for clastic rocks of the McArras Brook and Martin Road formations. Plots showing compositional fields of the late Devonian granitic rocks of the Cobequid Highlands (COBP), sedimentary rocks of the Beechill Cove Formation (BCF), and Meguma Group metasedimentary rocks (MMS). For data sources, see Fig. 4.

data). The mafic volcanic rocks of the McArras Brook Formation are another potential source.

In the Cobequid Highlands, Neoproterozoic rocks are represented by the Jeffers Group, which is geochemically similar to the Georgeville Group (Murphy et al. 1992). Voluminous Late Devonian bimodal plutonic and volcanic rocks (Pe-Piper et al. 1989; Pe-Piper and Piper 1998) of the Cobequid Highlands are compared with the McArras Brook and Martin Road clastic rocks due to their proximal location to the west and northwest of the study area. The Caledonian Highlands of southern New Brunswick, which predominantly consists of Neoproterozoic metavolcanic and metasedimentary rocks intruded by Neoproterozoic plutonic rocks, are also considered a potential source area, because structural and paleoenvironmental data indicate uplift at some time during the Carboniferous (e.g., Nance1987).

The Late Cambrian to Early Ordovician metasedimentary rocks of the Meguma Group and Late Devonian granitic rocks of the Meguma terrane in southern Nova Scotia (Clarke et al. 

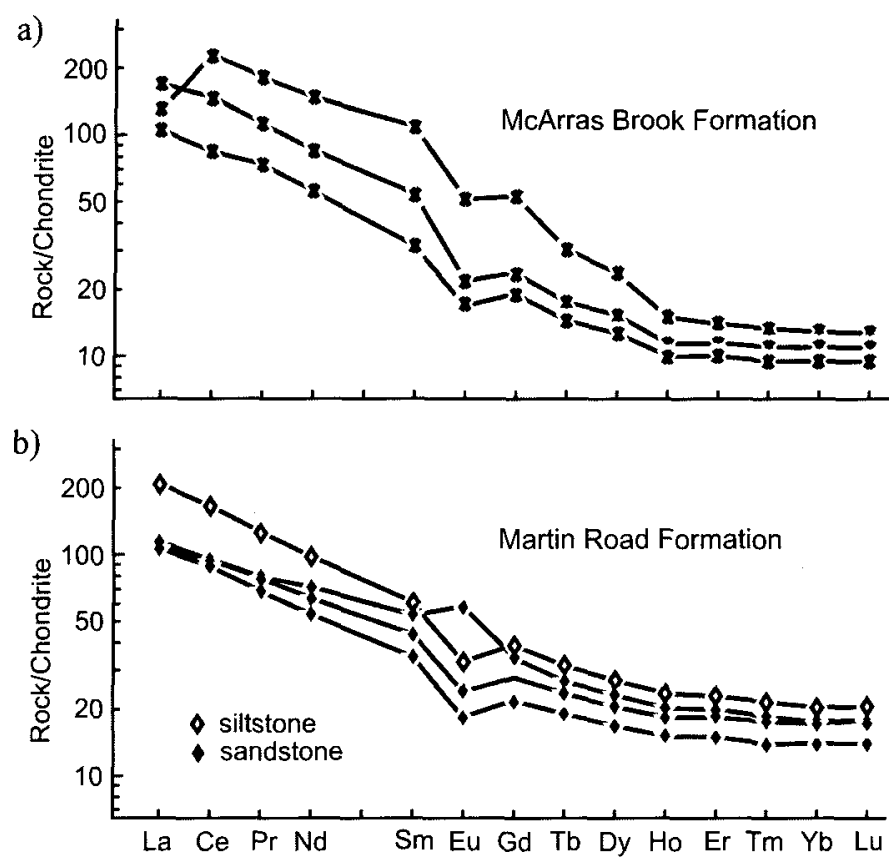

Fig. 6. Chondrite normalized REE plots for (a) clastic rocks of the McArras Brook Formation and, (b) clastic rocks of the Martin Road Formation.

$1988,1997)$ are compared, to test whether significant uplift and erosion of the Meguma terrane occurred during the deposition of either the McArras Brook or the Martin Road formations (see Keppie and Dallmeyer 1995; Dallmeyer et al. 1997).

\section{Interpretation}

Late Precambrian Avalonian rocks, represented by the clastic sedimentary rocks of the Georgeville Group of the Antigonish Highlands (Murphy and MacDonald 1993), the Middle to Late Devonian mafic rocks of the Cobequid Highlands (Pe-Piper and Murphy 1989; Pe-Piper and Piper 1989), and the mafic rocks of the Caledonian Highlands (Barr 1987), do not appear to be significant contributors to the detrital chemistry of either the McArras Brook or Martin Road formations. The Late Precambrian formations each plot in distinct fields on the trace element ratio plots, with little overlap with either Paleozoic formation (Fig. 3, 4). For example, both formations are characterized by relatively constant $\mathrm{Ti} / \mathrm{Nb}$ over a range of $\mathrm{Zr} / \mathrm{Nb}, \mathrm{Zr} / \mathrm{Y}$, and $\mathrm{Zr} / \mathrm{V}$. In contrast, Avalonian suites such as the Georgeville Group, and Late Devonian Cobequid granitoid rocks display positive correlations between $\mathrm{Ti} / \mathrm{Nb}, \mathrm{Zr} / \mathrm{Nb}$ and $\mathrm{Zr} / \mathrm{Y}$. The Georgeville Group has higher $\mathrm{Ti} / \mathrm{Nb}$ and the Cobequid granitoids have lower $\mathrm{Ti} / \mathrm{Nb}$ than the McArras Brook and Martin Road formations. Other suites, such as the Caledonian Highlands mafic rocks and the Cobequid mafic rocks, have much wider ranges in $\mathrm{Ti} / \mathrm{Nb}$ than the limited range of the Martin Road Formation.

The McArras Brook mafic volcanic rocks have lower $\mathrm{Zr} / \mathrm{Nb}$ and higher $\mathrm{Ti} / \mathrm{Nb}$ than the McArras Brook and Martin Road sedimentary rocks. The Meguma Group metasedimentary rocks also have a wide range in $\mathrm{Ti} / \mathrm{Nb}$ and

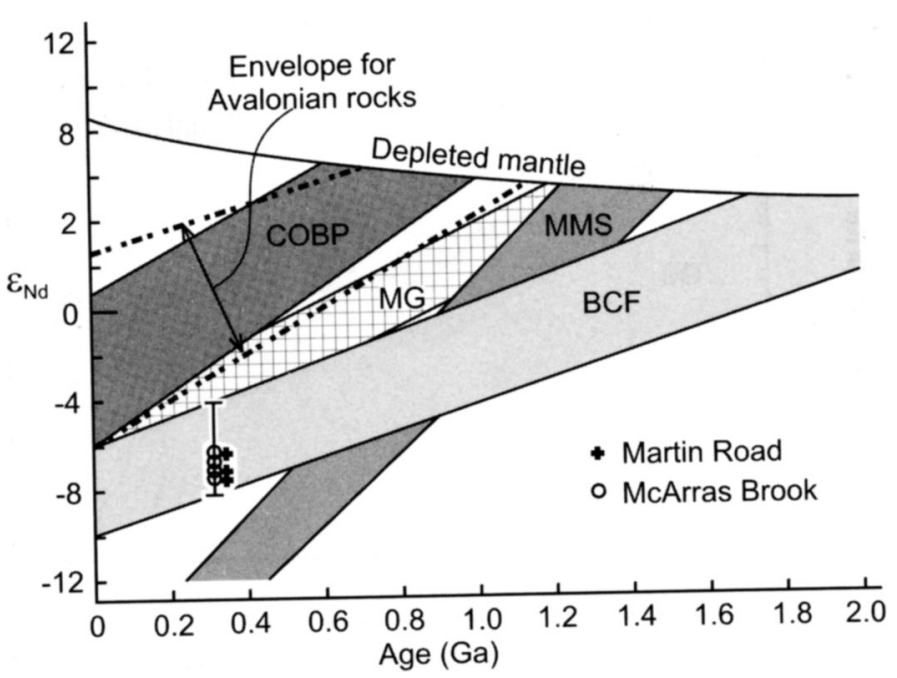

Fig. 7. Plot of $\varepsilon_{N d}$ vs. age for the McArras Brook and Martin Road formations. $\mathrm{T}_{\mathrm{DM}}$ ages are given in Table 3. Symbols as in Fig. 6. Envelope for Avalonian rocks from Murphy et al. (1996), Late Devonian Cobequid granitoid plutons (COBP) from Pe-Piper and Piper (1998), Beechill Cove Formation (BCF) from Murphy and MacDonald (1993), Meguma Granite (MG) and Meguma metasedimentary rocks (MMS) from Clarke et al. $(1988,1993)$.

the Meguma granitoids have lower Ti/Nb. McArras Brook and Martin Road sedimentary rocks display similar inter-element ratios and trends to the Beechill Cove Formation. However, the slightly lower $\mathrm{Ti} / \mathrm{Nb}$ in the McArras Brook and Martin Road formations relative to the Beechill Cove Formation could be achieved by mixing with a relatively minor proportion $(<5 \%$ ) of granitoid rock (either Meguma or Cobequid granitoids).

On other trace element plots, such as $\mathrm{Y} / \mathrm{V}$ vs. $\mathrm{Ti} / \mathrm{Zr}, \mathrm{Zr} / \mathrm{Y}$ vs. $\mathrm{Ti} / \mathrm{Y}$, and $\mathrm{Zr} / \mathrm{V}$ vs. $\mathrm{Ti} / \mathrm{V}$, the geochemical similarities between the clastic rocks of the McArras Brook Formation, the Martin Road Formation, and the Beechill Cove Formation are also apparent (Fig. $4 \mathrm{a}-\mathrm{c}$ ). In contrast, the Meguma and Cobequid granitoid rocks have lower $\mathrm{Ti} / \mathrm{Y}, \mathrm{Zr} / \mathrm{Y}$ and higher $\mathrm{Y} / \mathrm{V}$ and $\mathrm{Zr} / \mathrm{V}$; the Georgeville Group, Meguma metasedimentary rocks, Caledonian Highlands and the Cobequid mafic rocks have higher $\mathrm{Ti} / \mathrm{Y}$ and $\mathrm{Ti} / \mathrm{Zr}$.

The REE profiles of the Georgeville Group and the mafic rocks of the Cobequid Highlands show lower LREE patterns and lack a prominent Eu anomaly in comparison to the McArras and Martin Road formations (Fig. 8a, b). Although the LREE and HREE patterns of the Cobequid granitoid rocks are somewhat similar to those of the McArras Brook and Martin Road formations, the granites have higher values and a more pronounced negative Eu anomaly (Fig. 8b). The granitic rocks of the Meguma terrane have lower REE values and a more pronounced negative Eu anomaly. The HREE and LREE patterns of the Meguma Group metasedimentary rocks are similar to those of the McArras Brook and Martin Road formations although the sedimentary rocks of the Martin Road Formation have a more prominent negative Eu anomaly (Fig. 8c). The REE abundances of the McArras Brook, Martin Road and Beechill Cove formations are similar (Fig. 6, Fig. 8a), although only one McArras Brook sample contains the unusual positive $\mathrm{Ce}$ anomaly, and lacks a Eu anomaly. 

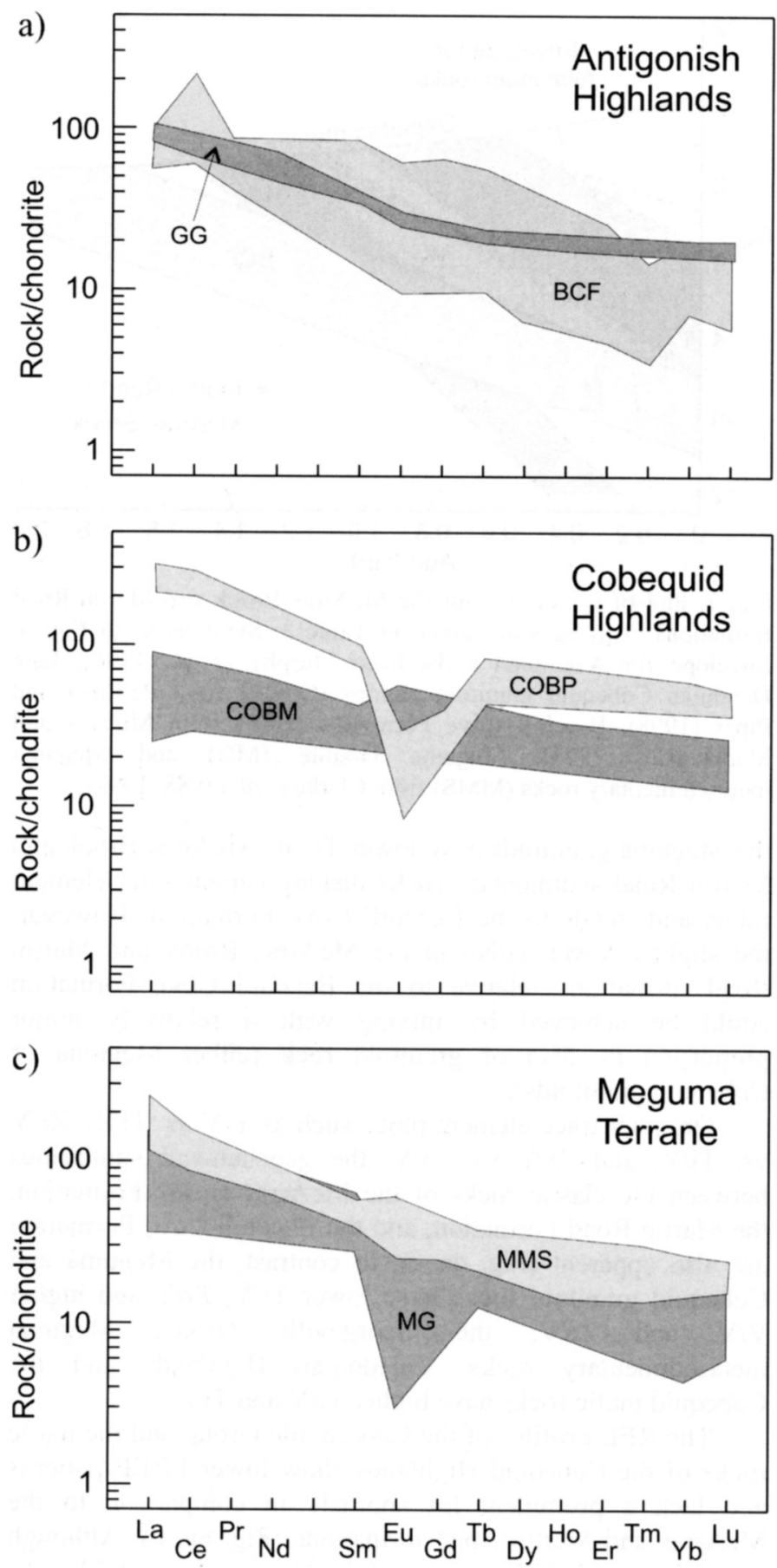

Fig. 8. Summary of chondrite-normalized REE data for (a) the Antigonish Highlands (GG, Georgeville Group, BCF, Beechill Cove Formation), (b) the Cobequid Highlands (COBP, Late Devonian Cobequid Granitoid plutons, COBM, Late Devonian Cobequid mafic rocks), and (c) the Meguma terrane (MMS, metasedimentary rocks, MG, Meguma Granite). Data sources as in Fig. 4.

The $\varepsilon_{N d}$ values for the clastic rocks of the Georgeville Group $\left(\varepsilon_{N d}=0.2-4.4\right)$ and the Devonian mafic rocks of the Cobequid Highlands $\left(\varepsilon_{N_{d}}=0.8-4.8\right)$ are significantly higher than the $\varepsilon_{\mathrm{Nd}}$ values in the McArras Brook or Martin Road formations when calculated for a $320 \mathrm{Ma}$ depositional age, and fall within the envelope of typical Avalonian rocks (Fig. 7; Murphy et al. 1996; Nance and Murphy 1994). Both suites

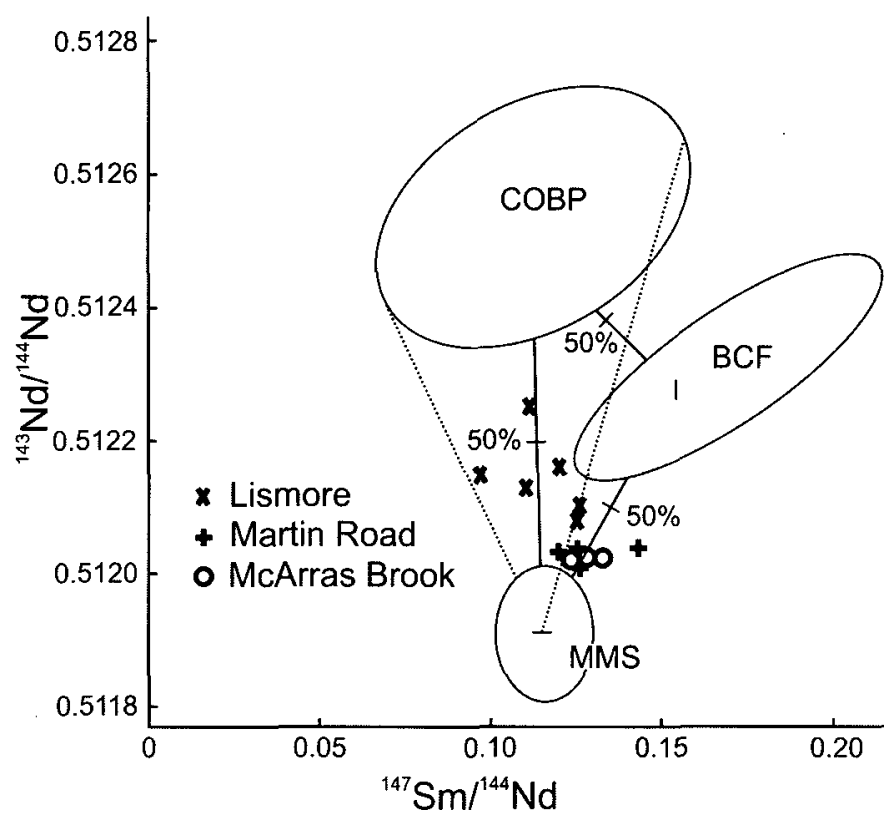

Fig. 9. ${ }^{147} \mathrm{Sm} /{ }^{144} \mathrm{Nd}$ vs. ${ }^{143} \mathrm{Nd} /{ }^{144} \mathrm{Nd}$ plot for the McArras Brook and Martin Road clastic rocks showing potential mixing curves of the metasedimentary rocks of the Meguma Group (MMS) with the sedimentary rocks of the Beechill Cove Formation (BCF) and the Late Devonian granitic rocks of the Cobequid Highlands (COBP). Mixing curves from Langmuir et al. (1978). Namurian Lismore Formation samples included for comparison (from Stevens et al. 1999).

of granitic rocks have higher (less negative) $\varepsilon_{\mathrm{Nd}}$ values (Cobequid Highlands, $\varepsilon_{\mathrm{Nd}}=-1.7$ to 4.0, and Meguma terrane, $\varepsilon_{\mathrm{Nd}}=-1.4$ to -3.8$)$ than the McArras Brook and Martin Road formations when calculated for a $320 \mathrm{Ma}$ depositional age (Fig. 7). The above data suggest that none of these suites are dominant sources for a Nd isotopic signature of either the McArras Brook or the Martin Road formations. The $\varepsilon_{N_{d}}$ values for the metasedimentary rocks of the Meguma Group $\left(\varepsilon_{\mathrm{Nd}}=\right.$ 7.5 to -10.0 ), when calculated for a $320 \mathrm{Ma}$ depositional age, are more negative than those of the McArras and Martin Road formations (Fig. 7). The $\varepsilon_{N d}$ values for the Beechill Cove Formation $\left(\varepsilon_{\mathrm{Nd}}=-4.8\right.$ to -6.1$)$ are similar to that of the McArras Brook and Martin Road formations when calculated for a $320 \mathrm{Ma}$ depositional age and the $\varepsilon_{\mathrm{Nd}^{-}}$-age plot (Fig. 7).

There is evidence in the Sm-Nd isotopic signature for a subtle influence from the Meguma terrane metasedimentary rocks. On a ${ }^{147} \mathrm{Sm} / \mathrm{d}^{144} \mathrm{Nd}$ versus ${ }^{143} \mathrm{Nd} /{ }^{144} \mathrm{Nd}$ plot, (Fig. 9) both formations have ${ }^{143} \mathrm{Nd} /{ }^{144} \mathrm{Nd}$ values that lie between those of the Beechill Cove and Meguma metasedimentary rocks, suggesting a mixed source. The apparent discrepancy between this plot and the trace element ratio plots (which indicate very limited influence from Meguma terrane rocks) can be explained by processes such as incongruent dissolution of host minerals and selective sorting during sediment transport. As a result, the relative contributions of various source regions to the trace element and isotopic geochemistry may differ. The ${ }^{147} \mathrm{Sm} /{ }^{144} \mathrm{Nd}$ vs. ${ }^{143} \mathrm{Nd} /{ }^{144} \mathrm{Nd}$ diagram indicates the importance of isotopic systematics in identifying a contribution from terranes that may otherwise be difficult to demonstrate. 
In summary, the geochemical and isotopic signatures of the McArras Brook and Martin Road formations are similar to that of the Beechill Cove Formation, suggesting that these formations are predominantly sourced from the adjacent rocks in the Antigonish Highlands. However, the isotopic signature suggests some input from the Meguma terrane to the south.

\section{TECTONIC SIGNIFICANCE}

The deposition of the McArras Brook and Martin Road formations occurred during two important time intervals in the development of the Maritimes Basin. The mid-to-late Devonian McArras Brook Formation represents a sequence deposited immediately preceding or in the earliest stages of development of the basin. Deposition of the Viséan Martin Road Formation occurred during, or immediately following, uplift and erosion, which is represented by the McArras Brook-Martin Road angular unconformity, and one of the unconformities that interrupt the Late DevonianCarboniferous sequence along the southern flank of the Maritimes Basin. However, in terms of basin development, the significance of the episodes of deformation that resulted in these unconformities is unknown.

A comparison between the geochemical signature of clastic sedimentary rocks above and below angular unconformities may aid in this analysis. For example, the uplift and erosion associated with regional unconformities can result in profound changes in drainage systems. As a result, clastic rocks above and below these unconformities may have different provenance and chemical composition.

There is little in the geochemical and isotopic signatures of the McArras Brook and Martin Road formations that cannot be attributed to local sources. These formations are more similar to one another and to the underlying Beechill Cove Formation than to any other potential source. This suggests that the deformation, uplift and erosion prior to deposition of the Martin Road Formation, that is represented by the McArras Brook-Martin Road angular unconformity, was a localized event, possibly related to motion along the Hollow Fault during the Early Viséan. This interpretation is consistent with other sedimentological evidence suggesting Early Viséan movement along the Hollow Fault (Chandler et al. 1997).

At present, because of the lack of geochemical data on Carboniferous clastic rocks, it is not possible to assess whether the unconformity represents a far-field expression of a major episode in the evolution of the Maritimes Basin, or a local response to stresses along the Hollow Fault. However, the approach of using geochemical and isotopic data to compare provenance above and below unconformities in various parts of the Maritimes Basin may provide important insights into the relationship between sediment deposition and tectonic activity along the basin margins.

\section{ACKNOWLEDGMENTS}

Supported by the Natural Sciences and Engineering Research Council, the Canada-Nova Scotia Mineral Development Agreement, and a St. F.X. University Council of
Research Grant. I am grateful to Sandra Barr, Fred Chandler, Lorne Jennex, and Jackie Stevens for discussions and to Les Fyffe and Georgia Pe-Piper for constructive, thoughtful reviews. Contribution to IGCP 453.

\section{REFERENCES}

BARR, S.M. 1987. Field relations, petrology, and age of plutonic and associated metavolcanic and metasedimentary rocks, Fundy National Park area, New Brunswick. In Current Research, Part A. Geological Survey of Canada, Paper 87-1A, pp. 263-280.

BhatiA, M.R., \& CROOK, K.A.W. 1986. Trace element characteristics of greywackes and tectonic setting discrimination of sedimentary basins. Contributions to Mineralogy and Petrology, 92, pp. 181-193.

Boucot, A.J., Dewey, J.F., Dineley, D.L., Fyson, W.K., HickoX, C.F., McKerrow, W.S., AND Ziegler, A.M. 1974. Geology of the Arisaig Area. Geological Society of America, Special Paper 139, p 191.

BRAdLEY, D.C. 1982. Subsidence in Late Paleozoic Basins in the Northern Appalachians. Tectonics, 1, pp. 107-123.

CHANDLER, F.W. 1997. Tectonics, paleoclimate and sandstone-hosted base metal deposits: cause and effect in the Carboniferous Maritimes Basin, Eastern Canada. Geological Association of Canada - Mineralogical Association of Canada Program with Abstracts, 22, p. A24.

CHANDleR, F.W. 1998. Geology and climatic indicators in the Westphalian A New Glasgow Formation, Canada: implications for the genesis of coal and of sandstone-hosted lead deposits. Atlantic Geology, 34, pp. 39-56.

Chandler, F.W., Waldron, J.W.F., Giles, P., \& Gall, Q. 1997. Geology of the Stellarton Gap, Nova Scotia, NTS 11 E/10 and parts of NTS 11/E7, 9, 15. Geological Survey of Canada Open File 3535, scale 1: 50,000.

Clarke, D.B., Halliday, A.N., \& Hamilton, P.J. 1988. Neodymium and strontium isotopic constraints on the origin of peraluminous granitoids of the South Mountain Batholith, Nova Scotia. Chemical Geology, 73, pp. 15-24.

Clarke, D.B., Chatterjee, A.K., \& Giles, P.S. 1993. Petrochemistry, tectonic history, and Sr-Nd systematics of the Liscomb Complex, Meguma Lithotectonic Zone, Nova Scotia. Canadian Journal of Earth Sciences, 30, pp. 449-464.

Clarke, D.B., MacDonald, M.A., \& TATE, M.C. 1997. Late Devonian mafic-felsic magmatism in the Meguma Zone, Nova Scotia. In Magmatism in the Appalachians. Edited by A.K. Sinha, J.B Whalen, and J.P. Hogan. Geological Society of America Memoir 191, pp. 107-127.

DAllmEYER, R.D., KePPIE, J.D., \& NANCE, R.D. $1997 .{ }^{40} \mathrm{Ar} /{ }^{39} \mathrm{Ar}$ ages of detrital muscovite within the Lower Cambrian and Carboniferous clastic sequences of northern Nova Scotia and southern New Brunswick: implications for provenance regions. Canadian Journal of Earth Sciences, 34, pp. 156-168.

DePaOLO, D.J. 1981. Neodymium isotopes in the Colorado Front Range and crust-mantle evolution in the Proterozoic. Nature, 29, pp. 193-196.

DEPAOLO, D.J. 1988. Neodymium isotope geochemistry: an introduction. Springer Verlag, New York, N.Y., U.S.A. 187 p.

DonohoE JR., H.V., \& Wallace, P. 1985 Repeated orogeny, faulting, and stratigraphy in the Cobequid Highlands, Avalon Terrane of Northern Nova Scotia. Geological Association of Canada, Field guide Excursion 3.

FENG, R., \& KERRICH, R.1990. Geochemistry of fine-grained clastic sediments in the Archean Abitibi greenstone belt, Canada: implications for provenance and tectonic setting. Geochimica et 
Cosmochimica Acta, 54, pp. 1061-1081.

FraliCK, P.W. 1980. Tectonic and sedimentological development of a late Paleozoic wrench basin: the eastern Cumberland Basin, Maritime Canada. Unpublished M.Sc. thesis, Dalhousie University, Halifax, Nova Scotia, 188 p.

Fralick, P.W., \& SCHENK, P.E. 1981. Molasse deposition and basin evolution in a wrench tectonics setting: the Late Paleozoic, Eastern Cumberland Basin, Maritime Canada. In Sedimentology and tectonics in Alluvial Basins. Edited by A.D. Miall. Geological Association of Canada Special Paper 23, pp. 77-97.

GiBLING, M.R. 1995. Upper Paleozoic rocks, Nova Scotia. In Chapter 5 of the Appalachian-Caledonian Orogen in Canada and Greenland. Edited by $\mathrm{H}$. Williams. Geological Survey of Canada, No. 6, pp. 493-523 (also Geological Society of America, The Geology of North America, v. F-1).

Gibling, M.R., CAlder, J.H., Ryan, R., VAN DE Poll, H.W., \& YeO, G.M. 1992. Late Carboniferous and Early Permian drainage patterns in Atlantic Canada. Canadian Journal of Earth Sciences, 29, pp. 338-352.

Ham, L.J., MarSh, S.W., COREY, M.C., HoRne, R.J., \& MaCDONald, M.A. 1989. Lithogeochemistry of the Eastern Portion of the South Mountain Batholith, Nova Scotia. N.T.S. Map Sheets $11 \mathrm{D} / 05,11 \mathrm{D} / 12,11 \mathrm{D} / 13,21 \mathrm{~A} / 09,21 \mathrm{~A} / 10,21 \mathrm{~A} / 15,21 \mathrm{~A} / 16$, and parts of $21 \mathrm{H} / 01$ and $21 \mathrm{H} / 02$. Nova Scotia Department of Mines and Energy Open File Report 89-001, 31 p.

Hamblin, A.P., \& RuSt, B.R. 1989. Tectono-sedimentary analysis of alternate-polarity half-graben basin-fill successions: Late Devonian-Early Carboniferous Horton Group, Cape Breton Island, Nova Scotia. Basin Research, 2, pp. 239-255.

Holland, H.D. 1978. The chemistry of the atmosphere and oceans. Wiley, New York, N.Y., U.S.A., 351 p.

JaCobSEn, S.B., \& WASSERBuRG, G.J. 1980. Sm-Nd evolution of chondrites. Earth and Planetary Science Letters, 50, pp. 139155 .

KePPIE, J.D. 1982. The Minas Geofracture. In Major Structural Zones and Faults of the Northern Appalachians. Edited by P. St-Julien and J. Beland. Geological Association of Canada Special Paper 24, pp. 263-280.

KEPPIE, J.D. 1993. Synthesis of Paleozoic deformational events and terrane accretion in the Canadian Appalachians. Geologische Rundschau, 82, pp. 381-431.

KePPIE, J.D., \& DAllmeYER, R.D. 1995. Late Paleozoic collision, delamination, short-lived magmatism and rapid denudation in the Meguma Terrane (Nova Scotia, Canada): constraints from ${ }^{40} \mathrm{Ar} /{ }^{39} \mathrm{Ar}$ isotopic data. Canadian Journal of Earth Sciences, 32, p. 644-659.

KePpie, J.D., GILES, P.S., \& Boehner, R.C. 1978. Some Middle Devonian to Lower Carboniferous Rocks of Cape George, Nova Scotia. Nova Scotia Department of Mines Paper 78-4.

LA FLĖCHE, M.R., \& CAMIRÉ, G. 1996. Geochemistry and provenance of metasedimentary rocks from the Archean Golden Pond Sequence (Casa Berardi mining district, Abitibi subprovince). Canadian Journal of Earth Sciences, 33, pp. 676-690.

LANGMUiR, C.H., VoCKe, R.D., HANSON, G.N., \& HART, S.R. 1978. A general mixing equation with applications to Icelandic basalts. Earth and Planetary Science Letters, 37, pp. 380-392.

LONGERICH, H.P., JENNER, G.A., Fryer, B.J., \& JACKSON, S.E. 1990. Inductively coupled plasma-mass spectrometric analysis of geologic samples: a critical evaluation based on case studies. Chemical Geology, 83, pp.105-118.

Martel, A.M., \& GiBling, M.R. 1991. Wave-dominated lacustrine facies and tectonically controlled cyclicity in the Lower Carboniferous Horton Bluff Formation, Nova Scotia, Canada. In Lacustrine Facies Analysis. Edited by P. Anadon, L. Cabrera, and $\mathrm{K}$. Kelts. International Association of Sedimentologists
Special Publication 13, pp. 223-243.

MCCUTCHEON, S.R., \& RoBinson, P.T. 1987. Geological constraints on the genesis of the Maritimes Basin, Atlantic Canada. In Sedimentary Basins and Basin-Forming Mechanisms. Edited by C. Beaumont and A.J. Tankard. Canadian Society of Petroleum Geologists Memoir 12, pp. 287-297.

Mclennan, S. M., Hemming, S., MCDaniel, D. K., \& Hanson, G.N. 1993. Geochemical approaches to sedimentation, provenance, and tectonics. In Processes Controlling the Composition of Clastic Sediments. Edited by M.J. Johnsson and A. Basu. Geological Society of America Special Paper 284, pp. 21-40.

MilleR, B.V., NANCE, R.D., \& MuRPhY, J.B. 1995. Kinematics of the Rockland Brook Fault, Nova Scotia, implications for the interaction of the Meguma and Avalon Terranes. Journal of Geodynamics, 19, pp. 253-270.

MURPHY, J.B. 2000. Tectonic influence on sedimentation along the southern flank of the Late Paleozoic Magdalen Basin in the Canadian Appalachians: geochemical and isotopic constraints on the Horton Group in the St. Mary's Basin, Nova Scotia. Geological Society of America Bulletin, v. 112, pp. 991-1011.

MuRPhy, J.B., \& MACDONALD, D.L. 1993. Geochemistry and tectonic discrimination of Late Proterozoic arc-related volcaniclastic turbidite sequence, Antigonish Highlands, Nova Scotia. Canadian Journal of Earth Sciences, 30, pp. 2273-2282.

MurPhy, J.B., KEPPIE, J.D., \& HYNES, A.J. 1991. Geology of the Antigonish Highlands. Geological Survey of Canada Paper 89$10,115 \mathrm{p}$.

Murphy, J.B., Pe-Piper G., Keppie J.D., \& PiPer D.J.W. 1992. Correlation of Neoproterozoic III sequences in the Avalon Composite Terrane of mainland Nova Scotia: tectonic implications. Atlantic Geology, 28, pp. 147-153.

Murphy, J.B., KepPie, J.D., Dostal, J., Waldron, J.W.F., \& Cude, M.P. 1995. Geochemical and isotopic characteristics of Early Silurian clastic sequences in the Antigonish Highlands, Nova Scotia, Canada: constraints on the accretion of Avalonia in the Appalachian-Caledonide Orogen. Canadian Journal of Earth Sciences, 33, pp. 379-388.

Murphy, J.B., Keppie, J.D., Dostal, J., \& Cousens, B.L. 1996. Repeated lower crustal melting beneath the Antigonish Highlands, Nova Scotia: Nd isotopic evidence and tectonic implications. In Avalonian and related peri-Gondwana terranes of the North Atlantic. Edited by R.D. Nance and M.D. Thompson. Geological Society of America Special Paper 304, pp. 109-120.

Murphy, J. B., Pe-Piper, G. PiPer, D.J.W., NANCE, R.D., \& Doig, R. 2001. Geology of the eastern Cobequid Highlands. Geological Survey of Canada Bulletin 556, 61 p.

NANCE, R.D. 1987. Dextral transpression and Late Carboniferous sedimentation in the Fundy coastal zone of southern New Brunswick. In Sedimentary Basins and Basin-Forming Mechanisms. Edited by C. Beaumont \& A.J. Tankard. Canadian Society of Petroleum Geologists Memoir 12, pp. 363-378.

NANCE, R.D., \& MuRPHY, J.B. 1994. Contrasting basement signatures and the palinspastic restoration of peripheral orogens: example from the Neoproterozoic Avalonian - Cadomian Belt. Geology, 22, pp. 617-620.

Naylor, R.D., Kalkreuth, W., Smith, W.D., \& Yeo, G.M. 1989. Stratigraphy, sedimentology, and depositional environments of the coal-bearing Stellarton Formation, Nova Scotia. Geological Survey of Canada Paper 89-8, pp. 2-13.

Nelson, B.K., \& DePAOLO, D.J. 1988. Comparison of isotopic and petrographic provenance indicators in sediments from Tertiary continental basins of New Mexico. Journal of Sedimentary Petrology, 58, pp. 348-357.

Pe-Piper, G., \& MurPhy, J.B. 1989. Geochemistry and tectonic 
setting of the late Precambrian Folly River Formation, Cobequid Highlands, Avalon Terrane, Nova Scotia: a continental rift within a volcanic-arc environment. Atlantic Geology, 25, pp. 143-151.

Pe-PIPER, G., \& PIPER, D.J.W. 1989. The Late Hadrynian Jeffers Group, Cobequid Highlands, Avalon Zone of Nova Scotia: a back arc volcanic complex. Geological Society of America Bulletin, 101, pp. 364-376.

PE-PIPER, G., \& PIPER, D.J.W. 1998. Geochemical evolution of Devonian-Carboniferous igneous rocks of the Magdalen Basin, eastern Canada. $\mathrm{Pb}$ and $\mathrm{Nd}$ evidence for mantle and lower crustal sources: Canadian Journal of Earth Sciences, 36, pp. 201-221.

Pe-Piper, G., Murphy, J.B., \& Turner, D.S. 1989. Petrology, geochemistry, and tectonic setting of some Carboniferous plutonic rocks of the eastern Cobequid Hills. Atlantic Geology, 25 , pp. 37-49.

Ryan, R.J., \& Boehner, R.C. 1994. Geology of the Cumberland Basin, Cumberland, Colchester, and Pictou Counties, Nova Scotia. Nova Scotia Department of Natural Resources, Mines and Energy Branches Memoir 10, $222 \mathrm{p}$.

Ryan, R.J., Calder, J.H., Donohoe JR., H.V., \& NAYloR, R. 1987. Late Paleozoic Sedimentation and Basin Development adjacent to the Cobequid Highlands Massif, Eastern Canada. In Sedimentary Basins and Basin-Forming Mechanisms. Edited by C. Beaumont and A.J. Tankard. Canadian Society of Petroleum Geologists Memoir 12, pp. 311-317.

SCHENK, P.E. 1991. Event and sea level changes on Gondwana's margin: the Meguma Zone (Cambrian-Devonian) of Nova Scotia, Canada. Geological Society America Bulletin, 103, pp. $512-521$.

Stevens, J.E., Murphy, J.B., \& Chandler, F.W. 1999. Geochemistry of the Namurian Lismore Formation, northern mainland Nova Scotia: sedimentation and tectonic activity along the southern flank of the Maritimes Basin. Canadian Journal of Earth Sciences, 36, pp. 1655-1669.

TAYloR, S.R., \& MCLEnNAN, S.M. 1985. The Continental Crust: its composition and evolution. An examination of the geological record preserved in sedimentary rocks. Blackwell Scientific Publications, Oxford, U.K., 312 p.

UtTING, J. 1987. Palynology of the Lower Carboniferous Windsor Group and Windsor-Canso Boundary Beds of Nova Scotia, and their equivalents in Quebec, New Brunswick and Newfoundland. Geological Survey of Canada Bulletin 374, 93 p.

Waldron, J.W.F., Durling, P.W., Gillis, K.S., \& Howells, K. 1997. Namurian to post-Westphalian deformation history along the Cobequid-Hollow Fault system at the southern margin of the Maritimes Basin. Geological Association of Canada Mineralogical Association of Canada Program with Abstracts, $v$. 22, p. A156.

Williams, H. (1979). The Appalachian orogen in Canada. Canadian Journal of Earth Sciences, 16, pp. 792-807.

YeO, G.M., \& RuIXIANG, G. 1986. Late Carboniferous dextral movement on the Cobequid-Hollow Fault system, Nova Scotia: evidence and implications. In Current Research, Part A. Geological Survey of Canada Paper 86-1 A, pp. 399-410.

YeO, G.M., \& RuIXIANG, G. 1987. Stellarton Graben: an upper Carboniferous pull-apart basin in northern Nova Scotia. In Sedimentary Basins and Basin-Forming Mechanisms. Edited by C. Beaumont and A.J. Tankard. Canadian Society of Petroleum Geologists Memoir 12, pp. 299-309.

Editorial responsibility: Sandra M. Barr 